\title{
THE RELATIONSHIP BETWEEN RIPARIAN VEGETATION AND THE TROPHIC STRUCTURE OF AQUATIC MACROINVERTEBRATE COMMUNITIES WITHIN THE GREATER YeLLOWSTONE AREA
}

\author{
PETER G. MEIER $\downarrow$ DAVID F. TRAVERS \\ UNIVERSITY OF MICHIGAN $\downarrow$ SCHOOL OF PUBLIC HEALTH
}

\begin{abstract}
$\downarrow \quad$ ABSTRACT
This study investigated the effects of reduced vegetation cover on stream ecosystems within the Greater Yellowstone Area. The emphasis of the research concerned whether these effects express themselves within the aquatic macroinvertebrate community. Three general vegetation categories, each comprising three to four streams, were used to distinguish gradations of riparian vegetation: dense cover (control), moderate cover, and low cover. Within each site, five aquatic macroinvertebrate samples were collected from riffle areas with a Hess sampler. The organisms were identified to the lowest practicable taxonomic level and assigned to trophic groups on the basis of gut content analysis. Riparian and in-stream variables also were measured. Statistical analyses were performed to elicit significant differences in riparian, stream, and insect community indices among the streams and to relate the structure (i.e., density, diversity, trophic organization) of the insect assemblage to the riparian and stream variables. The analysis of the data yielded no statistically significant differences among the vegetation categories with respect to embeddedness, bank overhang, and several physicochemical indices of water quality. Similarly, macroinvertebrate densities, biomass, and species richness did not differ among the categories. The trophic group analysis, however, revealed that the abundance and
\end{abstract}

biomass indices of the scraper community were significantly greater within the low cover sites than within the other streams. Conversely, the indices of the shredder community were significantly higher within the control streams than within the other sites. It is proposed that a shift from allochthonous to autochthonous food resources, corresponding to the different vegetation gradients, accounted for these observations. Of critical importance is the fact that the nominally shredder genera were not excluded from or even reduced in abundance within the low cover streams, but rather seemed to have adapted to the decline in allochthonous matter by shifting their mode of food acquisition from shredding to gathering. The implications of such trophic generalism for understanding the structure and function of aquatic macroinvertebrate communities are discussed.

\section{$\downarrow \quad$ INTRODUCTION}

This study investigated the effects of riparian vegetation cover on riparian and stream habitats within the Greater Yellowstone Ecosystem, which encompasses both the Grand Teton National Park and Yellowstone National Park. The emphasis of the research concerned how these effects express themselves within the aquatic macroinvertebrate community. 
Three general vegetation categories were used to distinguish gradations of riparian vegetation: dense cover (control), moderate cover, and low cover. The sites classified as having moderate cover exhibited clear evidence of browsing in the form of a very distinct horizontal browse line. Given, however, the difficulty or impossibilty of determining whether the absence of riparian vegetation owes to intense ungulate browsing or other factors unrelated to browsing (e.g., climate, fire frequency), the low cover classification cannot be used as an accurate surrogate measure for the intensity of ungulate feeding. The study, nonetheless, offers insight into the effects of browsing on stream ecosystems, by establishing statistically significant associations between riparian vegetation cover and the aquatic macroinvertebrate community.

\section{The Effects of Riparian Alteration on Stream Ecosystems}

Several studies have addressed the influence of canopy reduction on aquatic macroinvertebrate communities. $\mathrm{Li}$ et al. (1994) observed that macroinvertebrate biomass increased with decreasing canopy and increasing algal biomass. Although data regarding the diversity of the macroinvertebrate community were not collected, Li et al. (Tait et al. 1994) hypothesize that the effects of livestock grazing in the forms of open canopy and higher siltation changed the macroinvertebrate composition toward species less palatable for trout. The authors also surmise that temperature played a greater role in altering macroinvertebrate diversity than siltation.

In an examination of clear-cut riparian areas, Murphy et al. (1981) and Hawkins et al. (1982) concluded that these sites possessed higher abundance and diversity of macroinvertebrates than shaded sites. Murphy et al. (1981) found that i) the respiration associated with organic matter (a measure of food quality) was nearly three times greater in clear-cut areas, ii) the aufwuchs standing crops were twice as high in clear-cut sites, iii) the density of macroinvertebrates ranged from 1.5 to 2.3 times greater in clear-cut sites, and iv) within riffle habitats, the biomass of macroinvertebrates was 2.3 times that of shaded sites. (Hawkins et al. 1982) confirmed these results noting higher amounts of aufwuchs and higher quality detritus (respiration rate and chlorophyll $a$ content) within clear-cut sites. They also observed that abundances of macroinvertebrate guilds (collector-gatherers, filterers, shredders, and predators) were associated with different environmental variables depending on whether samples were taken from pool or riffle habitats. In a series of experiments with tray samples, the authors found that the number of taxa was highest in trays with no shading, faster currents, and the greatest proportion of sand. An analysis of communities in open and shaded sites revealed differences in dominance-diversity. The authors found that the absence of canopy increased the abundance of some of the dominant taxa found in shaded areas, thereby reducing species evenness.

Murphy and Hill (1981) reported greater biomass, density, and species richness of predators within high-gradient streams located in clear-cut sites than in old growth and second growth forests. However, the enhancing effects of opening the canopy were tempered in low gradient streams by an increase in sedimentation.

In the only study to examine the influence of livestock grazing on several indices of macroinvertebrate community structure (i.e., aside from biomass), Rinne (1988) found that grazed areas contained greater densities and biomass of macroinvertebrates. The variety of species identified in the grazed areas collectively exhibited higher tolerance quotients (a measure of sensitivity to pollution) than those species in ungrazed sites. Furthermore, ungrazed areas had higher Biotic Condition Index values (a measure of the quality of stream habitat) than grazed sites.

\section{Possible Mechanisms Involved in the Alteration of Stream Habitat}

Three environmental factors have been identified as the primary means through which riparian vegetation may structure macroinvertebrate communities:

Increase of Insulation:

With the reduction or elimination of canopy, the stream receives greater quantities of light which translate into higher primary productivity (Newbold et al. 1980, Murphy et al. 1981, Hawkins et al. 1982, Behmer and Hawkins 1986, Fuller et al. 1986, Wesche et al. 1987, Barmuta 1988, Hill and Knight 1988, Feminella et al. 1989, Lamberti et al. 1987, Carlson et al. 1990, DeNicola 1992, Dudgeon and Chan 1992, Steinman 
1992, Li et al. 1994) and higher temperatures (Platts and Nelson 1989). The impact of elevated temperature, however, may induce physiological stress in some macroinvertebrates (Bisson and Davis 1976). Sweeney (1978, 1984), Vannote and Sweeney (1980), and DeWalt and Stewart (1994) found that increased temperatures shorten larval growth and development periods which may result in decreased adult size. Considering that the relationship between egg production and female dry weight appears linear for some species, higher temperatures may reduce macroinvertebrate fecundity, or conceivably improve it for warmer temperature species.

If the thermal equilibrium hypothesis proposed by Vannote and Sweeney (1980) has validity, then it is possible that macroinvertebrate fecundity and ultimately community structure could change significantly in response to an increase or decrease in temperature. They suggest that species differ in their physiological responses to temperature such that different species may have different ranges of optimal temperatures. Deviations from this optimal range will adversely affect the development, growth, and fecundity of the species (Corkum 1978, Orbdlik et al. 1979, Sweeney et al. 1986, Webb and Merritt 1987, Mundahl and Kraft 1988, Rosillon 1988, Soderstrom 1988). In addition, during the winter, the absence of vegetation cover may cause temperatures to fall below pre-disturbance levels, thereby impairing larval development and growth or inducing mortality through the formation of anchor ice (Winegar 1977). A change in the temperature regime may also disrupt the structure of a community. Vannote (1973) examined 5 congeneric species of Ephemerella having similar ecosystem function and found that seasonal temperature patterns seemed to be the critical factor in maintaining the differential emergence times responsible for effective resource partitioning.

\section{Increase in Sedimentation/Siltation:}

The removal of riparian vegetation may result in higher sediment loads which may alter substratum conditions by affecting water movement, food quantity and quality, oxygen availability, and interstitial spacing (Egglishaw 1980, Minshall 1984, Rinne 1988, Cobb and Flanagan 1990, Gupta and Michael 1992, Richards et al. 1993).

\section{Change in Allochthonous Material:}

A reduction in canopy followed in some cases by a shift in species composition of the riparian vegetation will affect the quantity and variety of allochthonous material which, in turn, may change the trophic structure of stream biota. With a decline in allochthonous material and a concomitant increase in authochthonous matter, scrapers, for instance, would replace shredders as the predominant functional group (Huryn and Wallace 1988, Richardson and Neill 1990, Stout et al. 1993, Tait et al. 1994, Morides et al. 1996, Friberg et al. 1997 and Mihuc 1997). Some studies have questioned the validity of applying functional feeding groups as an accurate means of characterizing the trophic nature of the aquatic macroinvertebrate community on the grounds that many species may exhibit generalist rather than specialist, or obligate, feeding behaviors (Mihuc and Minshall 1995, Mihuc and Mihuc 1995, Mihuc 1997). Species, therefore, may be able to adapt to the elimination or limitation of one resource by shifting to another, thus obscuring any relationship between functional feeding groups and their food resources.

Also, an absence or reduction of trees and shrubs will mean less woody debris in the stream which may improve (Murphy and Hall 1981) or reduce species diversity.

\section{METHODS}

\section{Site Selection}

Three general vegetation categories, each comprising three to four streams, were used to distinguish gradations of riparian vegetation: dense cover (control), moderate cover, and low cover. Each site was classified based on the height of the riparian vegetation (see the following section for details). Though the difference between a moderate cover site and either a control or low cover site might seem evident from a visual evaluation of riparian vegetation in the field, the ecological significance of this difference in terms of its effects on the stream biota was unclear. Nevertheless, the three category design provided the opportunity to examine the gradient of effects possibly associated with different levels of riparian vegetation cover. An additional survey in the spring of 1997 led to the inclusion of two more sites for the summer and fall 
sampling of 1997. Only one year of data, therefore, has been collected from these two sites (Table 1).

Table 1. Coordinates and altitudes of study sites.

\begin{tabular}{|l|c|c|c|c|}
\hline Site & Coordinates & $\begin{array}{c}\text { GPS Altitude } \\
\text { (feet) }\end{array}$ & $\begin{array}{c}\text { Topographic Map } \\
\text { Attitude (feet) }\end{array}$ & $\begin{array}{c}\text { Vegetation } \\
\text { Category }\end{array}$ \\
\hline Lake (C) & $\begin{array}{l}\text { N } 43^{\circ} 37.554^{\circ} \\
\text { W } 110^{\circ} 46.612^{\circ}\end{array}$ & 6720 & 6400 & Control \\
\hline Cache (C) & $\begin{array}{l}\text { N } 43^{\circ} 27.904^{\circ} \\
\text { W } 110^{\circ} 43.944^{\circ}\end{array}$ & 6690 & 6562 & Control \\
\hline Cottonwood (C) & $\begin{array}{l}\text { N } 43^{\circ} 42.595^{\circ} \\
\text { W } 110^{\circ} 43.863^{\circ}\end{array}$ & 6860 & 6688 & Control \\
\hline Bear (C) & $\begin{array}{l}\text { N } 45^{\circ} 04.491^{\circ} \\
\text { W } 110^{\circ} 37.876^{\circ}\end{array}$ & 6600 & NA & Control \\
\hline Little Granite (M) & $\begin{array}{l}\text { N } 43^{\circ} 19.079^{\circ} \\
\text { W } 110^{\circ} 30.338^{\circ}\end{array}$ & 6690 & 6562 & $\begin{array}{c}\text { Moderate } \\
\text { Cover }\end{array}$ \\
\hline Granite (M) & $\begin{array}{l}\text { N } 43^{\circ} 36.217^{\circ} \\
\text { W } 110^{\circ} 48.300^{\circ}\end{array}$ & 6219 & 6356 & $\begin{array}{c}\text { Moderate } \\
\text { Cover }\end{array}$ \\
\hline Coffiman (M) & $\begin{array}{l}\text { N } 43^{\circ} 37.045^{\circ} \\
\text { W } 110^{\circ} 47.289^{\circ}\end{array}$ & 6460 & 6425 & $\begin{array}{c}\text { Moderate } \\
\text { Cover }\end{array}$ \\
\hline Flat (H) & $\begin{array}{l}\text { N } 43^{\circ} 32.960^{\circ} \\
\text { W } 110^{\circ} 40.393^{\circ}\end{array}$ & 6500 & 6480 & $\begin{array}{c}\text { Low } \\
\text { Cover }\end{array}$ \\
\hline Deer (H) & $\begin{array}{l}\text { N } 43^{\circ} 57.259^{\circ} \\
\text { W } 110^{\circ} 35.399^{\circ}\end{array}$ & 6812 & 6720 & $\begin{array}{c}\text { Low } \\
\text { Cover }\end{array}$ \\
\hline Soda Bunte (H) & $\begin{array}{l}\text { N } 45^{\circ} 00.183^{\circ} \\
\text { W } 110^{\circ} 01.817^{\circ}\end{array}$ & 6880 & 7280 & $\begin{array}{c}\text { Low } \\
\text { Cover }\end{array}$ \\
\hline Pebble (H) & $\begin{array}{l}\text { N } 45^{\circ} 01.155^{\circ} \\
\text { W } 110^{\circ} 03.280^{\circ}\end{array}$ & 7900 & 8080 & $\begin{array}{c}\text { Low } \\
\text { Cover }\end{array}$ \\
\hline NA= Not Available & & & & \\
\hline
\end{tabular}

The streams differ in the magnitude of flow and thus, considering the potential importance of flow in influencing the stream biota and other variables of interest (Orth and Maughan 1983), the sites were stratified according to flow for the sake of inter-stream comparisons. The statistical analyses performed on the sites as stratified by flow are not presented here. Though the sites display a wide range of flows, there exists no consistent bias among the three categories for this variable.

Another potentially important source of spatial variation among the sites relates to the riparian vegetation. Six of the streams possess a riparian community comprised predominantly of willow (Salix spp.), and very secondarily of alder (Alnus incana), dogwood (Cornus stolonifera), and aspen (Populus tremuloides) while for five of the streams, Cottonwood Creek, Lake Creek, Bear Creek, Coffman Creek, and Flat Creek, the obverse applies with cottonwoods (Populus trichocarpa) or alder forming the predominant species. Of the latter, three belong to the control category, one to the moderate cover category, and one to the low cover category. Studies have demonstrated the varying influence of different plant species in providing food and habitat for the aquatic macroinvertebrates (Hynes 1970, Grubbs and Cummins 1996), and so the influence of riparian plant composition on the stream biota should not be discounted when considering the results.
Three of the low cover streams are located within the Northern Winter Range of Yellowstone Park. One of two such ranges in the park, this area of 250,000 acres provides a winter habitat for approximately 17,000 elk (Varley and Brewster 1992, John Mack and Roy Renkin, Yellowstone Center for Resources, personal communication). Riparian vegetation may experience heavy use during the winter months as snow cover and the relative unpalatability of grasses at this time make shrubs one of the few food resources available. Trampling of plants and soil compaction by elk herds may also play a role in reducing or eliminating riparian vegetation. These areas also receive use throughout the year from the moose population which numbers around 400 in the Northern Winter Range. The low cover site in the Grand Teton Park is located within the National Elk Refuge, an area of 26,000 acres that supports about 10,000 elk during the winter, though primarily through the provision of hay by the Refuge (James Griffin, National Elk Refuge, personal communication).

The control streams had comparatively tall, unforaged riparian vegetation that is indicative of minimal browsing activity. The assessment of browsing intensity was based on percent leader use and vegetation height. In general, the three moderate cover sites are characterized by riparian areas with shrubs lining most of the streams and with a few well-worn paths, formed by the wildlife, cutting through the banks. The shrubs generally exhibited a uniform horizontal browse line which rises to between $1-1.5 \mathrm{~m}$ in height. The low cover streams have far less canopy cover than shrubs at the control or moderate cover sites. Along one of the low cover streams, Flat Creek, much of the riparian vegetation has been removed completely or persists exclusively in a late succession phase, that is, denuded of shrubs with only mature trees lining the banks. It is important to note that the horizontal browse lines observed at the moderate and some low cover sites during the first year of the study became less uniform during the second year, with regrowth having occurred to an appreciable extent. Thus, the condition of the riparian vegetation would seem to vary considerably from year to year depending on a combination of climatic and browsing factors. 


\section{Riparian Variables}

A reach of $150 \mathrm{~m}$ was identified at each of the sites. The USGS recommends $150 \mathrm{~m}$ as a minimum length for performing macroinvertebrate studies (USGS 1993). Within the reach, a series of transects were placed at regular intervals (about $3 \mathrm{~m}$ ) along the sampling area for the evaluation of riparian variables in accordance with Platts et al. (1987) and Platts and Nelson (1985).

Aquatic and stream morphological variables were measured at each transect (Table 2, Myers and Swanson 1995).

Table 2. Riparian and instream variables.

\begin{tabular}{|l|l|}
\hline \multicolumn{1}{|c|}{ Variable } & \multicolumn{1}{c|}{ Measurement } \\
\hline substrate composition & percentage of substrate that is silt, sand, gravel, pebble, cobble \\
\hline embeddedness & percentage of substrate that is surrounded by sand or silt \\
\hline bank stability & percentage of stable banks \\
\hline canopy & percentage of streamside vegetation \\
\hline channel width:depth & ratio of werted width to average depth \\
\hline
\end{tabular}

The condition of riparian vegetation also was assessed by measuring vegetation height, leader use, and vegetation overhang. These variables were measured along 6 randomly selected transects within the reach. Vegetation height was measured as the distance from the base of the plant to the highest leader. Leader utilization was estimated as the percentage of leader consumption for all plants intersected by the transect within $2 \mathrm{~m}$ of the stream. Vegetation overhang was measured from the streambank edge to the tip of the plant extending into the stream.

\section{Water Quality Measurements}

Water quality measurements and samples were collected from the first transect from which macroinvertebrate samples were collected. Dissolved oxygen (DO), $\mathrm{pH}$, temperature, conductivity, and turbidity were measured with a portable Horiba Water Quality Checker U10. Alkalinity, hardness, total suspended solids (TSS), and chlorophyll $a$ were measured in accordance with Standard Methods (APHA 1992).

The analysis of nutrients $\left(\mathrm{NO}_{3}, \mathrm{NH}_{4}\right.$, Total P) was performed by Dr. Thomas Johengen at the Great Lakes Environmental Research Laboratory in Ann Arbor.

\section{Autochthonous and Allochthonous Material}

Periphyton was measured from rocks collected within the transect from which the macroinvertebrate samples were taken. An effort was made to collect rocks of uniform size and shape so as to reduce variability among the samples, and thus the periphyton samples have not been randomnly selected. The rocks were scrubbed with a toothbrush within a plastic pan until its surface no longer felt slimey. During the scrubbing, the rock was occassionally rinsed with distilled water. The water which collected in the pan was placed into a dark $250 \mathrm{ml}$ polyeurythane bottle. About $10 \mathrm{ml}$ of saturated magnesium carbonate solution were added to the bottle as a preservative.

The standing crop of periphyton was analyzed for ash-free dry matter (AFDM), chlorophyll $a$, and composition of algal species. The chlorophyll $a$ analysis was performed in accordance with the procedures described in Standard Methods (APHA 1992).

The AFDM of the periphyton was obtained by filtering between 5 and $10 \mathrm{ml}$ of the periphyton through a Whatman $.45 \mu \mathrm{m}$ glass fiber filter which had been preburned in a muffler furnace at $500^{\circ} \mathrm{C}$ for 20 minutes to account for any loss of mass associated with the heating process. The filter was placed in a drying oven at $55^{\circ} \mathrm{C}$ for 24 hours and then weighed. The filter was next placed in a muffler furnace at $500^{\circ} \mathrm{C}$ for 1 hour and then weighed again for AFDM.

Allochthonous matter was measured from the benthos collected with the Hess sampler. After the macroinvertebrates were removed from the benthos, the stream bed material was sieved using two different mesh sizes, $200 \_\mathrm{m}$ and $1 \mathrm{~mm}$, to separate fine particulate organic matter (FPOM) from coarse particulate organic matter (CPOM). The mesh size of the Hess sampler was 300 m and so this method likely underestimated the amount of allochthonous material in the $200 \_\mathrm{m}$ to $1 \mathrm{~mm}$ size class. The material trapped in the sieves was placed in an aluminum tray of $4 \mathrm{~cm}$ or $20 \mathrm{~cm}$ in diameter, depending on the volume of the sample, which had been preburned in a muffler furnace at $500^{\circ} \mathrm{C}$ for 20 minutes. The trays were transferred to a drying oven at $65^{\circ} \mathrm{C}$ for 24 hours and then weighed. The samples were placed into a muffler furnace where they were ashed at $500^{\circ} \mathrm{C}$ for 1 hour and then weighed again for AFDM. 


\section{Macroinvertebrate Sampling}

The macroinvertebrate samples were collected with a modified Hess sampler $\left(.08 \mathrm{~m}^{2}\right)$ as described by Mackay and Kalff (1969). Five samples were obtained from riffle areas within nine streams between August 4-9 and October 5-8 of 1996 and again within eleven streams between July 17-21 and October 3-7 of 1997.

The macroinvertebrates were preserved in $70 \%$ ethanol and transported to the University of Michigan where the organisms were hand-picked from the debris and preserved in $70 \%$ ethanol. Identification was performed to the lowest practicable taxonomic level, usually genus, using the keys of Merritt and Cummins (1996), Ward and Kondratieff (1992) and Wiederholm (1986).

Several indices were selected to contrast the macroinvertebrate communities among the study sites; the density of all species, species diversity (as measured by the number of genera), the density and biomass of trophic groups (i.e., scrapers, collectorgatherers, predators, shredders, and filterers), and the proportion of the density and biomass of trophic groups. The work of Mihuc and Minshall (1995) and Mihuc (1997), however, has questioned the validity of using functional feeding groups in light of the prevalence of generalist feeding strategies. The following procedure was developed to lend greater credibility to the trophic group assignments.

For each genus or species at every site, a gut content analysis was performed on one individual of each approximate size class from each of the five stations. If the species occurred at fewer than all five stations, then depending on its distribution, one individual was selected from four stations (if it appeared at just four stations), two from three stations, three from two stations, or five from one station. If the species was distributed such that the above scheme could not be applied, then some combination of individuals from each of the stations was collected to total five individuals. Where the density of a species was equal to or less than five, all of the individuals were analyzed and any ostensible difference in size noted. An improvement to the accuracy of this method would involve determining the age of the instar through the measurement of head capsule width. This procedure would ensure a more precise association between the age of the species and its corresponding food source compared with grouping insects according to approximate size class, as was performed in this study. Such a thorough method, though, would have required a great expenditure of time. The method used, therefore, reflects a compromise between addressing the potential deficiencies of using functional feeding groups and the time required to perform the gut content analysis.

Different size classes were examined as many species may alter their feeding behaviour at different stages of development (Gray and Ward 1979, Fuller and Mackay 1981, Sweeney and Vannote 1981, Li and Gregory 1989). For those genera having more than one size class at a site, it was common to find that only two size classes were present, usually a late instar and very early instar. Some of the genera (e.g., Baetidae Baetis, Nemouridae Zapada, Hydropsychidae Arctopsyche, Ryacophilidae Ryacophila), though, differed in size from very early instars to late instars. This variation may result from a lack of synchronous development and growth or may stem from the presence of congeneric species with varying development patterns.

The upper portion of the gut was removed from the thorax, placed on a slide containing a small droplet of water, and covered with a coverslip. The contents of the gut were examined under a Zeiss microscope at $400 \mathrm{X}$ in order to assign the insect to one of the five trophic groups. The following criteria were developed to perform this classification (Table 3 ).

Table 3. Trophic group classifications.

\begin{tabular}{|l|l|}
\hline Trophic Group & \multicolumn{1}{|c|}{ Gut Content Analysis } \\
\hline Serapers & $\begin{array}{l}\text { Algae comprise more than 33\% by volume of gut contenss with the } \\
\text { remainder consisting of dertital matter. }\end{array}$ \\
\hline Collector-Gatherers & $\begin{array}{l}\text { Algae comprise less than 33\% by volume of gut contents with the } \\
\text { remainder consisting of derrital matter. }\end{array}$ \\
\hline Predators & Insects present in gut. \\
\hline Shredders & Large particles of leaf matter present in gut \\
\hline Filterers & $\begin{array}{l}\text { Filterers were defined by feeding mechanism regardless of gut } \\
\text { contents. }\end{array}$ \\
\hline
\end{tabular}

The use of gut content analysis has not been standardized and thus the criteria presented in Table 3 represent a provisional means of classifying insects to trophic groups. The relative proportions of algae and detritus were estimated from a randomly selected portion of the gut employing a whipple disc in the eyepiece of the microscope. The use of $33 \%$ as the proportion of algae in the gut separating the scrapers and collector-gatherers was determined from an estimate of the relative significance of this food source in the diet. The underlying assumption is that an insect which 
consumes at least one-third of its diet in the form of algae probably derives a significant portion of its nutritional requirements from algae, and that, moreover, the ingestion of algae is not merely incidental to the ingestion of detritus. Whether this proportion serves to accurately discriminate between scrapers and collector-gatherers seems doubtful and consequently it should be revised on the basis of additional research. Also, it should be noted that the use of trophic groups in this context refers exclusively to the type of material present in the gut and not to the feeding mechanism by which the material has been obtained. Thus, the term scrapers is misleading in that it implies a morphological adaptation for removing algae, whereas in this study it refers to the proponderance of authochthonous material in the gut. What seems clear from this discussion is that if the functional feeding group classifications are to be discarded, then some standardized means must be proposed for the sake of uniformity before any other method is adopted.

For biomass measurements, the species belonging to each of the trophic groups were composited and placed on small circular aluminum trays (diameter of $3.2 \mathrm{~cm}$ ), which had been placed in an oven at $60^{\circ} \mathrm{C}$ for 24 hours prior to the analysis and then weighed on a Mettler H2O in order to account for any loss of mass from the drying process. The aluminum trays containing the trophic groups were placed in an oven at $55^{\circ} \mathrm{C}$ for 24 hours and then weighed again for the final biomass measurements.

\section{Statistical Methods}

The data were used to test the following hypthoseses :

$\mathbf{H}_{\mathbf{0}}$ 1: Riparian conditions do not differ significantly between (among) the categories. Individual null hypotheses include comparisons of streambank stability, vegetative use, vegetation height, vegetation overhang, and leader utilization.

$\mathbf{H}_{0}$ 2: Stream substrate conditions do not differ significantly between (among) the categories. Null hypotheses include comparisons of substrate composition and degree of embeddedness.

$\mathbf{H}_{\mathrm{o}}$ 3: Stream water quality variables do not differ significantly between (among) the categories. Comparisons include alkalinity, hardness, DO, temperature, TSS, chlorophyll $a$, and nutrients (N and $\mathrm{P})$.
$\mathbf{H}_{0}$ 3: Authochthonous and allochthonous materials do not differ significantly between (among) the categories. Null hypotheses include comparisons of periphyton, as measured by AFDM and chlorophyll $a$, and FPOM and CPOM.

$\mathbf{H}_{\mathbf{0}}$ 5: Macroinvertebrate communities do not differ significantly between (among) the categories. Null hypotheses include comparisons of density of collective taxa, species richness, and functional group density and biomass and relative proportions of density and biomass.

The variables for these null hypotheses were analyzed for homogeniety of variances and normality. These tests revealed that most of the variables were neither homogeneous in variance nor normally distributed and thus a $\log 10(\mathrm{x}+1)$ transformation was applied. The proportional data (i.e., percentages of trophic group density and biomass) were transformed with the $\arcsin (\mathrm{x})^{1 / 2}$ function as recommended by Zar (1984). If the transformations yielded homogeneous and normally distributed data, then a Tukey's test was performed to elicit differences among the categories.

Variables which were transformed without achieving homogenity of variances or normality were subjected to a bootstrap analysis. This method is an exact test which randomly resamples the data for a specified number of repetitions and randomly assigns each data point to a site within a treatment, i.e., it preserves the original sample design of the study. In an effort to discern whether any relationships existed between the trophic group variables and some of the environmental factors, regression models were developed by adding or removing the environmental (independent) variables based on their statistical significance in the model (as defined by the $\mathrm{p}$ value associated with the slope term of each variable). Pearson correlations were performed between the environmental variables to reveal collinearity among the variables.

All of the statistical analyses were performed using SAS- v.12 for Windows (SAS Institute Inc., 1996).

\section{$\downarrow \quad$ RESULTS \\ Chemical, Physical, and Biological Indices of Water Quality}

The chemical and physical measurements of water quality at each of the sites are presented in Tables 4 and 5 . These data suggest that while the sites exhibited some variation in the physical and 
chemical indices of water quality, no consistent expression of this variation was detected among the vegetation categories. The soft and moderately hard water streams, for instance, had a fairly even distribution among the three categories.

Table 4. Physicochemical measurements for August 1996.

\begin{tabular}{|c|c|c|c|c|c|c|c|c|}
\hline Site & $\begin{array}{l}\mathrm{pH} \\
(\mathrm{SU})\end{array}$ & $\begin{array}{c}\begin{array}{c}\text { Conductivity } \\
(\mathrm{mS} / \mathrm{cm})\end{array} \\
\end{array}$ & $\begin{array}{l}\text { Turbidity } \\
\text { (NTU) }\end{array}$ & $\begin{array}{c}\text { Dissolved Oxygen } \\
(\mathrm{mg} / \mathrm{L})\end{array}$ & $\begin{array}{c}\text { Total Suspended Solids } \\
(\mathrm{mg} / \mathrm{l})\end{array}$ & $\begin{array}{c}\text { Alkalinity } \\
\left(\mathrm{mg} \mathrm{CaCO}_{3} / \mathrm{L}\right)\end{array}$ & $\begin{array}{c}\text { Hardness } \\
\left(\mathrm{mg} \mathrm{CaCO}_{3} / \mathrm{L}\right)\end{array}$ & $\begin{array}{c}\text { Temperature } \\
\left({ }^{\circ} \mathrm{C}\right)\end{array}$ \\
\hline Lake (C) & 8.3 & 80 & $\overline{0}$ & 9.7 & 0.12 & 46 & 56 & 16.8 \\
\hline Cottonwood (C) & 7.6 & 12 & 0 & 11.2 & 0.14 & 10 & 16 & 17.3 \\
\hline Cache (C) & 8.7 & 280 & 0 & 11.4 & 3.80 & 162 & 184 & . 11.0 \\
\hline Little Granite (M) & 8.8 & 270 & 160 & 11.3 & 2.16 & 154 & 188 & 13.8 \\
\hline Granite (M) & 8.4 & 170 & 40 & 13.4 & 0.44 & 104 & 116 & 8.6 \\
\hline Coffman (M) & 8.2 & 100 & 50 & 13.4 & 1.25 & 94 & 82 & 9.6 \\
\hline Flat $(\mathrm{H})$ & 8.7 & 190 & 0 & 11.7 & 1.40 & 110 & 124 & 10.1 \\
\hline $\operatorname{Deer}(\mathrm{H})$ & 8.2 & 200 & 10 & 10.7 & 3.40 & 54 & 56 & 16.9 \\
\hline Soda Butte (H) & 8.4 & 120 & 200 & 12.9 & 3.04 & 74 & 84 & 8.6 \\
\hline
\end{tabular}

Table 5. Physicochemical measurements for October 1996.

\begin{tabular}{|lcccccccc|}
\hline Site & $\begin{array}{c}\text { pH } \\
(\mathrm{SU})\end{array}$ & $\begin{array}{c}\text { Conductivity } \\
(\mathrm{mS} / \mathrm{cm})\end{array}$ & $\begin{array}{c}\text { Turbidity } \\
(\mathrm{NTU})\end{array}$ & $\begin{array}{c}\text { Dissolved Oxygen } \\
(\mathrm{mg} / \mathrm{L})\end{array}$ & $\begin{array}{c}\text { Total Suspended Solids } \\
(\mathrm{mg} / \mathbf{)})\end{array}$ & $\begin{array}{c}\text { Alkalinity } \\
\left(\mathrm{mg} \mathbf{C a C O}_{3} / \mathrm{L}\right)\end{array}$ & $\begin{array}{c}\text { Hardness } \\
\left(\mathrm{mg} \mathbf{C a C O}_{3} / \mathrm{L}\right)\end{array}$ & $\begin{array}{c}\text { Temperature } \\
\left({ }^{\circ} \mathrm{C}\right)\end{array}$ \\
\hline Lake (C) & 8.7 & 10 & 50 & 11.3 & 0.34 & 48 & 52 & 13.2 \\
Cottonwood (C) & 7.3 & 0 & 0 & 10.6 & 0.47 & 4 & 20 & 15.0 \\
Cache (C) & 9.4 & 30 & 90 & 14.2 & 4.50 & 176 & 172 & 6.0 \\
Little Granite (M) & 9.1 & 30 & 0 & 13.7 & 5.10 & 180 & 182 & 4.0 \\
Granite (M) & 8.9 & 20 & 10 & 12.5 & 1.80 & 110 & 112 & 5.2 \\
Coffman (M) & 9.2 & 40 & 20 & 13.6 & 2.70 & 72 & 76 & 7.2 \\
Flat (H) & 9.6 & 20 & 20 & 12.6 & 1.42 & 120 & 120 & 12.0 \\
Deer (H) & 9.0 & 10 & 120 & 14.0 & 3.50 & 72 & 52 & 10.0 \\
Soda Butte (H) & 9.2 & 10 & 0 & 15.4 & 3.46 & 110 & 96 & 5.0 \\
\hline
\end{tabular}

\section{Macroinvertebrate Data: Genera}

Genera: August 1996

Perhaps the most immediately striking facet of the macroinvetebrate data concerns the uniformity of the composition of macroinvertebrate communities among the sites. Genera from the orders, Ephemeroptera, Plecoptera, Trichoptera, Coleoptera, and Diptera, comprise the majority of organisms for the sites. This finding conforms to the general description of insect communities within Rocky Mountain streams offerred by Ward (1992) who states that $95 \%$ of the species in such streams are represented by these orders with the remainder usually consisting of odonates and hemipterans. Within each of the predominant orders, the sites bear a remarkable degree of similarity to one another with respect to the composition of genera. For the mayflies, the genera common to most of the sites include Baetidae Baetis, Ephemerellidae Drunella and Seratella, and Heptageniidae Cinygmula and Epeorus. The most prevalent genera of the stoneflies are Chloroperlidae Plumiperla and Sweltsa, Nemouridae Zapada, and Perlodidae Cultus and Skwala. The dipterans were represented within many of the sites by Simullidae Simulium and various genera of the Chironomidae including Orthocladiinae Cricotopus, Orthocladius, Eukeferiella, Diamesinae Diamesa, and the Chironominae Tanytarsini Micropsectra. The most common genera among the trichopterans were Glossosomatidae Glossosoma, Brachycentridae Brachycentrus, Hydropsychidae Arctopsyche, and Ryacophilidae Ryacophila.

The uniformity of genera observed among the sites may stem from the equally marked degree of uniformity in the flow (or disturbance) regimes and substrate (or spatial heterogeniety) conditions prevailing at each of the sites. Both of these factors may have a deterministic influence in structuring the macroinvertebrate community (Towsend 1989, Townsend and Hildrew 1994). All of the sites, for instance, exhibit swift currents, rock and cobble substates, and a substantial increase of flow during spring snowmelt, in addition to the similarity of water quality indices dicsussed earlier. The genera common to the study sites all possess morphological traits, such as dorsoventral flattening, fusiliform shapes, elongated claws, grapples and hooks, or ballast, which may have evolved as adapatations to the periodic high flows and coarse substrate prevalent within Rocky Mountain streams. These 
factors singularly or in some combination may determine the species composition of the stream biota by serving as a filter for the wider range of species for which the habitat might otherwise have proven hospitable.

The mean number of genera among the sites differed significantly between Deer Creek (mean, $\mathrm{u}=21.4)$ and both Soda Butte Creek $(\mathrm{u}=15)$ and Coffman Creek $(u=14)$. The results from this analysis revealed no relationship between vegetation cover and the diversity of genera.

\section{Genera: October1996}

In October, 1996, the composition of genera among the sites had not undergone any dramatic alteration from the August data. The principal changes observed across most of the sites included the decline in the prevalence of Brachycentrus and the appearance of Taenionema, Megarcys, and Brillia.

The mean number of genera ranged from 16.4 (Coffman Creek) to 25.2 (Flat Creek) with no significant differences detected among any of the sites. Once again, no relationship was identified between vegetation cover and species diversity for this sampling date.

Genera: July 1997

The aquatic macroinvertebrates collected from the nine sites in July, 1997, were very similar in the composition of genera to the August, 1996, data.

The mean number of species of Cottonwood Creek $(u=20)$ and Cache Creek $(u=20.2)$ differed significantly from Soda Butte Creek $(u=12.4)$, otherwise no significant differences were detected. In the previous year, Deer Creek differed significantly from Soda Butte Creek and Coffman Creek in the mean number of genera. This shift between years may have resulted from the earlier collection of samples in the summer of 1997 or natural temporal variation within some of the study sites.

\section{Genera: October 1997}

The collection of samples in October, 1997, yielded a fauna very similar to the results obtained in October, 1996. As with the previous fall, Taenionema became one of the predominant genera within several of the streams including the two new sites. The October, 1997, data also mirrored the previous year in the disappearance of any statistically significant differences among the sites for the mean number of species.

\section{Macroinvertebrate Data: Densities}

\section{Macroinvertebrate Densities: August 1996}

A comparison of the mean densities among the sites revealed no statistically significant differences between the sites or vegetation categories.

\section{Macroinvertebrate Densities: October 1996}

The mean densities of macro invertebrates increased for eight of the nine sites in October, the exception being Flat Creek which, with the emergence of Simulium, exhibited a decline in mean abundance. The overall increase of mean densities in the fall resulted from the appearance of Taenionema and an increase in densities of genera present throughout most of the year, but for which abundances might have been lower in August due to spring emergence (e.g., Baetis, Hydropsyche). A comparison of mean densities revealed no significant differences among the sites or categories.

Macroinvertebrate Densities: July 1997

The mean densities for July, 1997, generally resemble those from August, 1996. A comparison of the means revealed no statistically significant differences among the sites or categories.

\section{Macroinvertebrate Densities: October 1997}

The mean densities of macroinvertebrates in October, 1997, deviate little from the results obtained in the fall of the previous year. A comparison of the mean densities among the sites revealed that Soda Butte Creek $(\mathrm{u}=834$ organisms $/ .08 \mathrm{~m} 2)$ and Cache Creek $(\mathrm{u}=728)$ differed significantly from Coffman Creek $(u=151)$, otherwise the sites possessed similar mean abundances. These results, and those from the other three sampling dates, therefore, failed to yield a relationship between the mean density of macroinvertebrates and vegetation cover. 


\section{Macroinvertebrate Data: Trophic Groups}

Statistical analyses were performed to elicit differences between the vegetation categories for all five trophic groups. However, only the results concerning the scapers and shredders are presented below, as these were the only two groups which exhibited consistent differences between the categories.

\section{Trophic Groups: August 1996}

Statistical analyses of the means of the three categories revealed significant differences for all four of the indices pertaining to the scraper community. The low and moderate cover sites had higher means for the density and biomass indices than the control sites. The moderate cover sites possessed higher mean proportional abundance and biomass than the low cover streams. The higher scraper indices reported from the moderate and low cover streams resulted from the greater abundance of scraper-classified ephemeropterans collected from these sites.

The vegetation categories exhibited significant differences for all four of the shredder indices. The control sites had higher means for each index than the low cover sites, and had significantly greater means of absolute abundance and proportional biomass than the moderate cover streams. The low cover streams possessed significantly fewer means for the absolute and proportional density and the absolute biomass of shredders than the moderate cover sites. These differences owed in large part to the distribution of shredder-classified Zapada among the sites, though Lepidostoma formed a critical component of the biomass index at Cottonwood Creek.

\section{Trophic Groups: October 1996}

The low cover streams collectively possessed higher indices for the scrapers than both the control and moderate cover sites. The moderate cover streams had a greater mean proportion of scrapers than the control streams. These differences arose due to the greater abundance of scraper-classified ephemeropterans and the plecopteran, Taenionema, within the moderate and low cover streams.

The four indices describing the shredder community were significantly higher within the control and moderate cover sites than the low cover sites (though a low cover site, Soda Butte Creek, had a higher absolute biomass of shredders than a control site, Cottonwood Creek). The proportional abundance of shredders was greater within the moderate cover sites than the control sites, though, obversely, the proportional biomass of shredders was higher within the control sites. The higher indices for the shredders were primarily attributable to the greater densities of shredder-classified Zapada within the control and moderate cover streams. The large sized Pteronarcys, however, comprised the majority of the shredder biomass within Lake Creek.

Trophic Groups: July 1997

The collective means for the absolute and proportional density of scrapers were greater within the low cover sites than both the control and moderate cover streams. The low cover streams possessed a higher abundance of scraper-classified ephemeropterans than the other sites.

A comparison of the collective mean for the shredder indices revealed that the controls had the highest mean for all four indices. In addition, the absolute and proportional number of shredders were greater within the moderate than the low cover streams. The spatial distribution of shredderclassified Zapada and Lepidostoma explain the differences detected among the categories.

Trophic Groups: October 1997

The low cover streams collectively had higher means for all four of the scraper indices than the control and moderate cover sites. As with the comparisons discussed earlier, these differences owed to the greater abundance of scraper-classified ephemeropterans and the plecopteran, Taenionema.

The mean absolute and proportional density of shredders were higher within the control and moderate cover streams than the low cover sites. The control sites collectively had a higher absolute and proportional biomass of shredders than the low cover sites. The control streams also had a higher mean for this index than the moderate cover sites but at a reduced level of significance $(p=.052)$. In accordance with the earlier results, the shredderclassified Zapada was largely responsible for these differences among the categories, though Perlomyia comprised a substantial portion of the shredder community within Bear Creek. 


\section{Autochthonous Organic Matter}

Periphyton: Chlorophyll a

For the periphyton samples collected in August, 1996, a comparison of the chlorophyll $a$ concentrations between the vegetation categories revealed no significant differences. The statistical analysis of the chlorophyll $a$ data from October, 1996, indicated that the low cover sites exhibited higher chlorophyll $a$ concentrations than the control and moderate cover streams. The results from October, 1997, showed that the control streams had lower concentrations than the moderate and low cover sites.

\section{Periphyton: Ash-Free-Dry-Matter (AFDM)}

Few statistically significant differences for AFDM were identified between the sites in August, 1996, and a comparison of AFDM means between the vegetation categories elicited no significant differences. In October, 1996, the control sites collectively possessed a lower AFDM concentration than the moderate cover sites. For the results from both July and October, 1997, the moderate and low cover sites had higher mean AFDM concentrations than the control sites for both sampling dates in 1997.

\section{Benthic Organic Matter (BOM): CPOM and FPOM}

The comparison between vegetation categories for August, 1996, revealed that the control and moderate cover sites had higher CPOM content than the low cover streams. For the October 1996 data, the inter-category analysis showed that the control sites had higher CPOM than the moderate and low cover sites, and also that the moderate cover streams had higher CPOM values than the low cover sites. The inter-category analysis for the July 1997 data indicated that the control streams exhibited a higher mean CPOM than the moderate and low cover sites. The results from the inter-category comparisons in October, 1997, were identical to those of October, 1996, with the control streams collectively having the highest mean CPOM and the moderate cover sites exhibiting a higher mean CPOM than the low cover sites. The results from the FPOM analysis revealed no significant differences between the sites or vegetation categories. It had been erroneously presupposed that the locations with higher CPOM values also would yield higher FPOM concentrations. Even if the process had not occurred on a local scale (i.e., within the collecting area of a Hess sampler), it had been expected that a reach scale effect would be observed. The absence of significant differences between the sites may result from the accumulation of FPOM within pools or runs rather than riffle areas. Further, the method of FPOM sampling may have proven an inferior substitute for the collection of benthic core samples which likely would have captured the distribution of both CPOM and FPOM with greater accuracy.

\section{Riparian and Instream Conditions}

\section{Bank Overhang, Embeddedness, Channel Width:Depth, Substrate Composition, Stream Bank Alteration}

The extent to which streambank had been undercut varied only slightly among the sites. Cottonwood Creek had significantly less bank overhang than Cache Creek and Deer Creek, and Little Granite Creek had less bank overhang than Deer Creek. A comparison of means between categories revealed no statistically significant differences for this variable. Similarly, the degree of embeddedness, substrate composition, channel width:depth, and the index of stream bank alteration did not differ significantly between the streams.

Vegetation Height

The average height of riparian vegetation differed significantly among the sites. A StudentNewman-Keuls test classified the control and moderate cover streams within groups which had higher mean vegetation heights than the groups consisting of the low cover streams. The intercategory analysis confirmed these results revealing that the control and moderate cover sites had taller vegetation than the low cover streams. The vegetation height of the control streams was higher than the moderate cover sites, but at a reduced level of significance $(\mathrm{p}=.067)$.

\section{Vegetation Overhang}

The average distance over which riparian vegetation extended horizontally from the bank edge to the stream surface differed signficantly among the sites. Consistent with the results above, the control and moderate cover sites were separated for the most part from the low cover streams in the 
Tukey's analysis. The inter-category comparisons revealed that the control streams exhibited the greatest extent of vegetation overhang of the sites, while the overhang at the moderate cover sites exceeded that of the low cover locations.

\section{Linear Modelling: Regressional and Correlation Analyses}

Correlation and Regression Analysis for the Scrapers

The significant correlation which persisted throughout the sampling period between chlorophyll $a$ and AFDM necessitated the use of partial correlation analyses between the scraper and these variables. The partial correlation analyses rendered many of the associations between the scrapers and the two measures of periphyton, chlorophyll $a$ and AFDM statistically insignificant. The biomass of scrapers for October, $1996(\mathrm{r}=.72, \mathrm{p}=.04)$ and 1997 ( $\mathrm{r}=.89, \mathrm{p}=.003)$, exhibited a positive correlation with the concentration of chlorophyll $a$. The density of scrapers in October, 1996, was correlated negatively with vegetation overhang $(r=-$ $.85, \mathrm{p}=.07)$. The positive association between scrapers and the amount of periphytic chlorophyll $a$ confirmed the findings of Behmer and Hawkins (1986), Fuller et al. (1986), Barmuta (1988), and Carlson et al. (1990). The negative correlation between scrapers and vegetation overhang may have resulted from the reduction of periphyton, particularly the chlorophyll $a$ component, caused by shading from the riparian vegetation. Scrapers may have avoided patches subject to shading in response to the relative decline of high quality periphyton, or in those cases where the riparian canopy might enclose the stream entirely, far fewer scrapers might populate the stream for lack of sufficient food resources. This supposition finds support from several studies which have observed a negative association between scraper densities and shading (Lamberti et al. 1987, Dudgeon and Chan 1992).

The identification of a significant correlation between scrapers and vegetation overhang implies that this relationship was expressed on a general level among the study sites. Nevertheless, inidvidual sites appear to have deviated from the general trend. The dense alder and willow stands lining the banks of Cache Creek, for instance, enveloped much of the stream and yet this site consistently harbored one of the most abundant scraper communities in terms of density and biomass. Thus, while a negative correlation may have prevailed among the sites between scrapers and vegetation overhang, departures from this relationship occurred, a fact which might explain the poor correlation between these two variables.

The regression analyses yielded significant linear relationships between the scrapers and chlorophyll $a$, otherwise no significant relationship were found between the scrapers and the riparian and stream variables. The concentration of periphytic chlorophyll $a$ explained in part the spatial variability of the number $\left(\mathrm{R}^{2}=.45, \mathrm{p}=.047\right)$ and biomass $\left(\mathrm{R}^{2}=.62, \mathrm{p}=.001\right)$ of scrapers in October, 1996, but predicted only the biomass of scrapers in October, $1997\left(\mathrm{R}^{2}=.49, \mathrm{p}=.02\right)$.

\section{Correlation and Regression Analyses for the Shredders}

The density $(\mathrm{r}=.76, \mathrm{p}=.006)$ and biomass $(\mathrm{r}=.56, \mathrm{p}=.07)$ of shredders were positively correlated with the quantity of CPOM in July, 1997. The correlation analysis also revealed that the density of shredders was positively correlated with CPOM in October, $1997(\mathrm{r}=.56, \mathrm{p}=.07)$. The riparian variables, vegetation overhang and height, were found to be positively correlated with the biomass of shredders in August, 1996 (vegetation overhang, $\mathrm{r}=.68, \mathrm{p}=.04)$, and with the density (vegetation overhang, $\mathrm{r}=.72, \mathrm{p}=.01$; vegetation height, $\mathrm{r}=.69, \mathrm{p}=.03$ ) and biomass of shredders in July, 1997 (vegetation overhang, $r=.76, p=.007$ ). The riparian variables, however, were positively correlated with one another and therefore these associations were reevaluated with partial correlation analyses. Moreover, correlation analyses revealed significant positive associations between CPOM and vegetation height for October, 1997, and for both sampling dates in 1997. As a consequence, partial correlation analyses also were applied to the associations found between the shredders and CPOM.

Partial correlation analysis between the shredders indices and CPOM (controlling for the riparian variables) eliminated the significance of the associations found in August, 1996, and July, 1997, but strenghtened the significance of the October, 1997, correlation between shredder density and CPOM $(r=.78, \mathrm{p}=.05)$. 
In addition to the correlation analyses performed between the means of the shredder indices and the means of the riparian and stream variables among the sites, correlation analyses were applied within each site to determine whether factors of a more local scale might influence the distribution of shredders. A correlation analysis was performed, therefore, for each site between the quantity of CPOM and the density and biomass of shredders at each of the five stations. Though the sample size for this analysis was very small $(n=5)$, several positive correlations were detected; Lake Creek, biomass, $\mathrm{r}=.87, \mathrm{p}=.056$; Bear Creek, biomass, $\mathrm{r}=.82, \mathrm{p}=.09$; Little Granite Creek, density, $\mathrm{r}=.90, \mathrm{p}=.04$; Flat Creek, biomass, $\mathrm{r}=.84, \mathrm{p}=.08$. Note, however, that most of these associations have a significance level of $\mathrm{p}>.05$.

The two indices of the shredder community, biomass and abundance, were considered as dependent variables and the riparian and instream measurments as independent variables for the purpose of performing linear regressions. The riparian variables, vegetation overhang and height, and the instream variable, CPOM, were found to predict one of both of the shredder indices for three of the sampling dates (Table 6). The fact that of the eight linear regressions, five occurred within July, 1997, suggested the influence of some common broad scale factor. The more pervasive relationship between the shredder community and the environmental variables may relate to the higher flows recorded within each of the streams in the summer of 1997.

Table 6. Regression models between shredders and riparian and stream variables.

\begin{tabular}{|c|c|c|c|}
\hline Date & Line ar Model & $\mathrm{R}^{2}$ & p value \\
\hline August, 1996. & $\log 10$ (biomass) $=.01+\$$ (vegetation overhang) +.177 & 0.47 & 0.04 \\
\hline August, 1996 & $\log 1 \alpha$ density) $=.117$ (vegetation height $)+.542$ & $0.37^{-}$ & 0.10 \\
\hline October, 1996 & $\log 10$ (biomass) $=.143$ (vegetation height) +.306 & 0.4 & 0.07 \\
\hline July, 1997. & $\log 10($ density $)=.020$ (vegetation overhang) +.211 & 0.62 & -0.01 \\
\hline July, 1997. & $\log 10$ (biomass) $=.0217$ (vegetation overhang).+ .141 & 0.60 & 0.01 \\
\hline July, 1997 & $\log 1 Q($ densiry $)=.12+($ vegetation height $) \pm .112$ & 0.60 & 0.02 \\
\hline July, 1997 & $\log 1 \underline{Q}($ density $)=.847(C P O M)+.289$ & 0.65 & 0.00 \\
\hline Julv. 1997 & loclorbiomass $)=.685(\mathrm{CPOM})+. .463$ & 0.40 & 0.04 \\
\hline
\end{tabular}

Though the seasonal and annual variation of CPOM within the sites did not exhibit any significant differences between sampling dates, the CPOM values for July, 1997, were the lowest of the four dates for ten of the streams. The higher flows, therefore, may have flushed some of the CPOM from the study reaches. The decline of CPOM may have enhanced the differences between the shredder communities among the sites, for the abundance of shredders may have been scarcely affected within those streams where adequate quantities of CPOM persisted despite the higher flows. Another explanation concerns the modest increase of sample size realized from the inclusion of two additional sites in 1997 which may have improved the power of the regression models. A further possibility involves the increase of the shredder indices recorded within Cottonwood Creek for July, 1997, which reflected the collection of greater densities of Lepidostoma immediately prior to emergence. The increase of shredder density and biomass within a site that also contained comparatively high quantities of CPOM improved the overall strength of the relationship between these variables. The latter two explanations, singularly or together, may present a more accurate understanding of these results, for the absence of significant annual variation in the shredder indices and CPOM values partially belies the validity of the first explanation.

The correlations obtained from the within stream (i.e., inter-station) data and the one significant correlation, after the inclusion of partial variables, from the inter-site data all emerged from one of the fall sampling dates. The seasonal correlation between mean shredder abundance and mean quantity of CPOM among the sites stemmed either from the coincidence of the shredders' life cycles with the influx of fall leaf litter or from the close association between the streams which supported abundant populations of shredders throughout the year and the streams which received large amounts of allochthonous matter in the fall. These explanations cannot be disentangled from one another for the reason that they may involve mutually inclusive influences, that is, the influx of leaf matter in the fall not only may prove critical for the growth and development of certain genera, but also may provide sufficient food resources in the form of slower decaying refractory materials to sustain the shredder community from the early spring to late summer months.

Moreover, the consequences of fall litter production may not be manifested to any discernible extent until some months later. Early instars of Lepidostoma, for instance, may depend on fall leaf litter to fulfil the dietary requirements attendant with their rapid growth, and yet the size and possibly distribution of this genus make it a relatively inconspicuous member of the macroinvertebrate 
community within riffle areas until the following winter or spring months.

The seasonal appearance of significant correlations between shredders and CPOM within some of the sites may have reflected the influence of somewhat different factors than those mentioned above, though perhaps not so much differerent factors as factors operating on a smaller scale. The correlation between shredder biomass and CPOM observed at Lake Creek owed for the most part to the presence of Pteronarcys and its selection of patches within riffles containing large quantities of leaf material. Increases in CPOM and the shredder, Zapada, accounted for the correlations within the other sites. In sum, it appeared that the distribution of shredders in the fall corresponded with the distribution of allochthonous food resources, both on an inter-site and inter-station scale.

\section{+ DISCUSSION}

The composition of trophic groups between the sites and vegetation categories revealed that the control sites possessed significantly greater density and biomass indices of shredders than the moderate or low cover sites for most of the sampling dates. An analysis conducted to distinguish differences of riparian and stream variables among the sites and categories indicated that the control sites exhibited significantly higher vegetation overhang and height than many of the other streams. It also was found that the control sites had significantly more CPOM than the low cover sites in the summer and more CPOM than both the moderate and low cover sites in the fall. And finally, correlation analyses showed that for some of the sampling dates, the abundance and biomass of shredders were associated positively with the quantity of CPOM, the latter of which, itself was correlated positively with the height of riparian vegetation. These results, considered in sum, suggest that the greater abundance of shreddders at the control sites owed to the greater abundance of CPOM and the greater height of riparian vegetation also recorded within the control sites. The moderate cover streams usually were placed between the control and low cover sites in terms of the indices relating to riparian vegetation, CPOM, and the shredder community. This finding lends additional credibility to the presupposition inherent in the sample design that the inclusion of the moderate cover sites might yield a gradient of effects which would strengthen the association between vegetation cover and the macroinvertebrate community.

The finding that the reduction of riparian vegetation may suppress shredder populations was not unexpected, as several studies have demonstrated a positive correlation between BOM and shredders (Stout et al. 1993, Morides 1996, though see Friberg 1997). Moreover, such a conclusion has an intuitive appeal, for it simply seems logical that a decline in riparian canopy would lead to a reduction in allochthonous material which, in turn, would depress the abundance of those oganisms dependent on this material as a food resource. And in a sense these initial hypotheses received validation from the results in that shredder populations did experience a decline in numbers and biomass within low cover sites. However, in another sense, these predictions proved erroneous, for the reason that the decline in shredder community failed to reflect the decline of genera classified under the functional feeding group scheme as shredders.

The majority of the shredder community, with respect to densities if not always biomass, consisted of Zapada for all of the study sites. Merritt and Cummins (1996) classified this genus as a shredder and studies in the Greater Yellowstone Area, as elsewhere, largely have accepted the accuracy of this classification. The analysis of the gut contents of Zapada, though, revealed considerable variation of diet both between instars of different sizes and between instars of the same size from different sites. Independent of site and vegetation cover, the early to mid instars consumed primarily small fragments of detritus along with an incidental quantity of diatoms, that is, a diet indicative of a collector-gatherer. The finding that the feeding behavior of early instars of Zapada apparently conforms more to that of a collectorgatherer than a shredder was not revelatory, for it has been widely acknowledged that the early instars of species may deviate from the feeding behaviour associated with the functional feeding group of later instars (e.g., in addition to Zapada, the study confirmed that some predaceous stoneflies feed largely on algae or deteritus as early instars).

The spatial variation in the diets of similarly sized mid to late instars of Zapada may represent the more significant finding. The later instars of Zapada within the low cover sites continued to consume much of its diet in the form 
of detrital matter and algae, that is, persisted in feeding as a collector-gatherer, though the guts of a few individuals contained shredded leaf material. Within the control sites, conversely, most of the later instars of Zapada had shifted to a diet comprised primarily of leaves. The low cover sites did not possess significantly fewer densities of Zapada than the control or moderate cover streams for any of the sampling dates. Rather the proportion of shredder-classified Zapada differs signficantly between the low cover streams and the other sites. Zapada, therefore, appears capable of adapting its feeding behavior in response to the availability of food resources. In the absence of sufficient quantities of CPOM, Zapada can survive as a collector-gatherer, however, in the presence of adequate supplies of CPOM, it will exist as a shredder, at least in later instars. The assignment of this genus into the shredder functional feeding group would have obscured entirely this interesting relationship.

These results and conclusions lend support to the work of Mihuc (1997), Mihuc and Mihuc (1995), and Mihuc and Minshall (1996), which has postulated that the wide prevalence of generalist feeding behavior among the aquatic macroinvertebrates warrants a reevaluation of the use of functional feeding groups. Mihuc and Minshall (1996) found that streams which had been denuded of riparian vegetation as a consequence of the 1988 fire within Yellowstone supported densities of Zapada similar to streams which had been unaffected by the fire. The authors, however, did not perform gut content analysis to determine whether the organsisms had shifted their feeding behaviour or whether sufficient quantities of CPOM still existed within the streams.

If some as yet indeterminate proportion of aquatic insects possesses the ability to shift their dietary intake in response to a limitation of food resources, then such flexibility would have implications for the influence of competition in structuring the macroinvertebrate community. The presence, for instance, of two or more species morphologically adapted to consume the same resource might occasion a competetive interaction over the efficiency with which these resources become translated into productivity gains. A conventional understanding of competition would predict that species occupying the same food niche would result either in coexistence, should the organisms prove equally capable of exploiting resources, or in exclusion, should one species exhibit a competitive edge in some regard (e.g., in feeding, reproduction, mobility, territoriality, etc.). The prevalence of trophic generalists, however, would seem to dampen the effects of competition at least with respect to the exploitation of food resources, as species may react to a decline in the availability of one food resource by simply switching to another. A decrease of food availability might be realized through a host of mechansims from the defense of territories to greater efficiency of consumption. Competition for food resources, therefore, may exert only a slight influence within an ecosystem characterized by trophic generalism.

The scraper group also displayed some association with vegetation cover. The low cover sites usually had greater abundance and biomass indices for the scrapers than the control and moderate cover streams. The low cover streams also had higher concentrations of AFDM and chlorophyll $a$ than the control sites. Correlation analysis revealed a postive association between the density of scrapers and the concentration of periphytic chlorophyll $a$, and a negative association between scrapers and vegetation overhang. These results indicate that the scraper community within the low cover sites responded favorably to the presence of high quality periphyton. The negative association between scrapers and vegetation overhang provided a possible link between this finding and vegetation cover. The reduction in riparian canopy may have increased the degree of insolation into the low cover streams and thereby promoted the productivity of algal and scraper communities. The failure, however, to detect a significant correlation between either chlorophyll $a$ or AFDM and one of the riparian variables imparts a more conjectural foundation to this conclusion than the positive correlation between CPOM and vegetation height allowed for the shredders.

\section{CONCLUSION}

This study found that streams of varying vegetation cover exhibited no differences with respect to stream embeddedness, bank overhang, temperature, and the principal indices of water chemistry. The results, though, indicated that through the reduction of riparian vegetation with a commensurate reduction of CPOM and possible increase of periphyton, vegetation cover did influence the structure of the aquatic 
macroinvertebrate community in terms not of species composition but of trophic status. The remarkable uniformity of species composition among the sites, irrespective of canopy cover, indicated that the redution in vegetation was not associated with the decline of any macroinvertebrate genera. Vegetation cover instead influenced the proportional and absolute extent of allochthonous and authochthonous material available to the aquatic insects, and thereby induced one of the principal shredders of these streams, Zapada, to undergo a change in its feeding behavior from that of a shredder to a collector-gatherer. Indeed, the populations of Zapada within the low cover sites attained a level of abundance comparable to the control streams, rather the difference between the vegetation categories lay in the proportion of mid to late instars classified as shredders. That the control and moderate cover sites contained greater quantities of CPOM than the low cover sites as a result of more extensive riparian vegetation likely accounted for the greater abundance of shredders within these streams. This conclusion was supported from the results of the regression and correlation analyses which revealed positive associations between shredders and either vegetation height or CPOM, both among the streams and among the stations within some of the streams.

\section{LITERATURE CITED}

American Public Health Association. 1996. Standard Methods for the Examination of Water and Wastewater. APHA, Wahington, D.C.

Barmuta, L.A. 1988. Benthic organic matter and macroinvertebrate functional feeding groups in a forested upland stream in temperate Victoria. Verhandlungen Internationale Vereinigung fur Theoretische und Angewandte 23:1394-1398.

Behmer, D.J., and C.P. Hawkins. 1986. Effects of overhead canopy on macroinvertebrate production in a Utah stream. Freshwater Biology 16:287-300.

Bisson, P.A., and G.E. Davis. 1976. Production of juvenile chinook salmon in a heated model stream. U.S. National Marine Fisheries Service Fishery Bulletin 74: 763-774.
Carlson, J.Y., C.W. Andros, and H.A. Froehlich. 1990. Woody debris, channel features, and macroinvertebrates of streams with logged and undisturbed riparian timber in northeast Oregon, USA, Canadian Journal of Fisheries and Aquatic Sciences 47:11031111 .

Caughley, G. 1976. Wildlife management and the dynamics of ungulate populations. In: T.H. Croaker (ed.). Applied Biology, v.1:183246. Academic Press, London.

Chadde, S.W. and C.E. Kay. 1991. Tall-willow communities on Yellowstone's Northern Range. In: R.B. Keiter and M.S. Boyce (eds.). The Greater Yellowstone Ecosystem: 231-262. Yale University Press, New Haven, Connecticut.

Chapman, D.W., and E. Knudsen. 1980. Channelization and livestock impacts on salmonid habitat and biomass in western Washington. Transactions of the American Fisheries Society 109: 357-363.

Cobb D.G., and J.F. Flannagan. 1990. Trichoptera and substrate stability in the Ochre River, Manitoba. Hydrobiologia 206: 29-38.

Corkum, L.D. 1978. The nymphal development of Paraletophlebiidae Adaptiva and P. Mollis and the possible influence of temperature. Canadian Journal of Zoology 56: 18421846.

DeNicola, D. 1992. Influences of canopy cover on spatial irradiance and periphyton assemblages in a prairie stream. Journal of the North American Benthological Society 11:391-404.

DeWalt, E.R., and K.W. Stewart. 1994. Life histories of stoneflies in the Rio Canejos of southern Colorado. Great Basin Naturalist 55(1): 1-18.

Dudgeon, D., and I.K.K. Chan. 1992. An experimental study of the influence of periphytic algae on invertebrate abundance in a Hong Kong stream. Freshwater Biology 27: 53-63. 
Egglishaw, H.J. 1980. Benthic invertebrates of streams on the Alburz mountain range near Tehran, Iran. Hydrobiologia 69: 49-55.

Feminella, J.W., M.E. Power, and V.H. Resh. 1989. Periphyton responses to invertebrate grazing and riparian cover in three northern Californian streams. Freshwater Biology 22: 445-457.

Friberg, N., M.J Winterbourne, K.A. Shearer, and S.E. Larsen. 1997. Benthic communities of forest streams in the South Island, New Zealand: effects of forest type and location. Archiv fur Hydrobiologie 138: 289-306.

Fuller, R.C., J.C. Roelofs, and T.J. Fry. 1986. The importance of algae to stream macroinvertebrates. Journal of the North American Benthological Society 5: 290296.

Fuller, R.C. and R. J. Mackay. 1981. Effects of food quality on the growth of three Hydropsyche species. Canadian Journal of Zoology 59: 1133-1140.

Gray, L.J. and J.V. Ward. 1979. Food habits of stream benthos at sites of differing food availability. American Midland Naturalist 102: $157-167$.

Grubbs, S.A. and K.W. Cummins. 1996. Linkages between riparian forest composition and shredder voltinism. Archiv fur Hydrobiologie 137: 39-58.

Gupta, A. and R.G. Michael. 1992. Diversity, distribution, and seasonal abundance of Ephemeroptera in streams of Meghalya state, India. Hydrobiologia 228:131-139.

Hawkins, C.P., M.L. Murphy, and N.H Anderson. 1982. Effects of canopy, substrate composition, and gradient on the structure of macroinvertebrate communities in Cascade range streams of Oregon. Ecology 63(6): 1840-1856.

Hill, V.R. and A.W. Knight. 1988. Concurrent grazing effects of two stream insects on periphyton. Limnology and Oceanography $33: 15-26$
Huryn, A.D., and J. B. Wallace. 1988. Community structure of Trichoptera in a mountain stream: spatial patterns of production and fnctional organization. Freshwater Biology 20:141-155.

Hynes, H.B.N. 1970. The Ecology of Running Waters. University of Toronto Press, Bungay, England.

Kay, C.E. 1997. Viewpoint: ungulate herbivory, willows, and political ecology in Yellowstone. Journal of Range Management 50: 139-145.

Lamberti, G.A., J.W. Feminella, and V.H. Resh. 1987. Herbivory and interspecific competition in a stream caddisfly population. Oecologia 73: 75-81.

Li, H. W., G.A. Lamberti, T.N. Pearsons, C.K. Tait, J.L Li, and J. C. Buckhouse. 1994. Cumulative effects of riparian disturbances along high desert trout streams of the John Day Basin, Oregon. Transactions of the American Fisheries Society 123: 627-640.

Li J.L., and S.V. Gregory. 1989. Behaviour changes in the herbivorous caddisfly Dicosmoecus gilvipes. Journal of the North American Benthological Society 8: 260269.

Mackay, R.J., and J. Kalff. 1969. Seasonal variation in standing crop and species diversity of insect communities in a small Quebec stream. Ecology 50: 101-109.

Merritt, R.W., and K.W. Cummins (eds.). 1996. An Introduction to the Aquatic Insects (3rd ed.). Kendall/Hunt Publishing. Dubuque, Iowa.

Mihuc, T.B. 1997. The functional trophic role of lotic primary consumers: generalist versus specialist strategies. Freshwater Biology 37: 455-462.

Mihuc, T.B. and G.W. Minshall. 1996. Species environment relationships among filterfeeding caddisflies in Rocky Mountain streams. Great Basin Naturalist 56: 287293. 
Mihuc, T.B. and J.R. Mihuc. 1995. Trophic Ecology of five shredders in a Rocky Mountain stream. Journal of Freshwater Ecology 10: 209-215.

Mihuc, T.B. and G.W. Minshall. 1995. Trophic generalists versus trophiuc specialists: implications for food web dynamics in post-fire streams. Ecology 76: 2361-2372.

Minshall, G.W. 1984. Aquatic insect-substratum relationships. In: V.H. Resh and D.M. Rosenberg (eds.). The Ecology of Aquatic Insects: 358-400. Praeger, New York.

Minshall, G.W., and J.N. Minshall. 1977. Microdistrubution of benthic macroinvertebrates in a Rocky Mountain stream. Hydrobiologia 55: 231-249.

Molles, M.C. 1982. Trichopteran communities of streams associated with aspen and conifer forests: long-term structural changes. Ecology 63(1): 1-6.

Morides, L., M. Philippe, J.G. Wasson, and J. Mathieu. 1996. Spatial and temporal distribution of macroinvertebrates and trophic variables within the bed sediment of three streams. Archiv fur Hydrobiologie 13:41-64

Mundahl, N. and K.J. Kraft. 1988. Abundance and growth of three species of aquatic insects exposed to surface release hydropower flows. Journal of the North American Benthological Society 7: 100-108.

Murphy, M.L., C.P. Hawkins, and N.H. Anderson. 1981. Effects of canopy modification and accumulated sediment on stream communities. Transactions of the North American Fisheries Society 110: 469-478.

Murphy, M.L. and J.D. Hall. 1981. Varied effects of clear-cut logging on predators and their habitat in small streams of the Cascade Mountains, Oregon. Canadian journal of Fisheries and Aquatic Sciences 38: 137145.
Myers, T.J. and S. Swanson. 1995. Impact of deferred rotation grazing on stream characteristics in central Nevada: A case study. North American Journal of Fisheries Management 15: 428-439.

Newbold, J.D., D.C. Erman, and K.B. Ruby. 1980. Effects of logging on macroinvertebrates with and without buffer strips. Canadian Journal of Fisheries and Aquatic Sciences 37:1076-1085.

Orbdlik, P., Z. Adamck, and t. Lohradka. 1979. Mayfly fauna and the biology of the species Potamanthus Luteus in a warmed stretch of the Oslava River. Hydrobiologia 67: 129140 .

Orth, D.J. and O. E. Maughan. 1983. Microhabitat preferences of benthic fauna in a woodland stream. Hydrobiologia 106: 157-168.

Platts, W.S., and R.L. Nelson. 1989. Stream canopy and its relationship to salmonid biomass in the intermountain west. North American Journal of Fisheries Management 9: 446-457.

Platts, W.S., and twelve coauthors. 1987. Methods for Evaluating Riparian Habitats with Applications to Mangement. US Forest Service Gen. Tech. Rep. INT-221, Ogden, Utah.

Platts, W.S. and R.L. Nelson. 1985a. Stream habitat and fisheries response to livestock grazing and instream improvement structures, Big Creek, Utah. Journal of Soil and Water Conservation. 40: 374-379.

Richards, C., G.E. Host, and J.W. Arthur. 1993. Identification of predominant environmental factors structuring stream macroinvertebrate communities within a large agricultural catchment. Freshwater Biology 29: 285-294.

Richardson, J.S. and W.E. Neill. 1990. Indirect effects of detritus manipulations in a montane stream. Canadian Journal of Fisheries and Aquatic Sciences 48: 776783. 
Rinne, J. N. 1988. Effects of livestock grazing exclosure on aquatic macroinvertebrates in a montane stream, New Mexico. Great Basin Naturalist 48(2): 146-153.

Rosillon D. 1988. Food preferences and relative influence of temperature and food quality on life history characteristics of a grazing mayfly, Ephemerella ignita. Canadian Journal of Zoology 66: 1474-1481.

SAS Institute Inc. 1996. SAS version 6.12 for windows. SAS Institute Inc., Cary, North Carolina.

Soderstrom, O. Effects of temperature and food quality on life-history parameters in Parameletus chelifer and $P$. minor: a laboratory study. Freshwater Biology 20:295-303.

Steinman, A.D. 1992. Does an increase in irradiance influence periphyton in a heavily grazed woodland stream? Oecologia 91: 163-170.

Stout, B.M., E.F. Benfield, and J.R. Webster. 1993. Effects of a forest disturbance on shredder production in southern Appalachian headwater streams. Freshwater Biology 29: 59-69.

Sweeney, B.W. 1984. Factors influencing life history patterns of aquatic insects. In: V.H. Resh and D.M. Rosenberg (eds.). The Ecology of Aquatic Insects: 56-100. Praeger, New York.

Sweeney, B.W., R.L. Vannote, and P.J. Dodds. 1986. Effects of temperature and food quality on growth and development of a mayfly, Leptophlebiidae Leptophlebia intermedia. Canadian Journal of Fisheries and aquatic Sciences 43: 12-18.

Sweeney, B.W. and R.L. Vannote. 1981. Ephemerella mayflies of White Clay Creek: bioenergetic and ecological relationships among the coexisting species. Ecology 62: 1353-1369.
Sweeney, B.W. 1978. Bioenergetic and developmental response of a mayfly to thermal variation. Limnology and Oceanography 23: 461-477.

Tait, C.K., J.L. Li, G.A. Lamberti, T.N. Pearsons, H.W. Li. 1994. Relationships between riparian cover and the community structure of high desert streams. Journal of the North American Benthological Society 13(1): 45-56.

Townsend, C.R. and A.G. Hildrew. 1994. Species traits in relation to habitat template for river systems. Freshwater Biology 31:265275.

Townsend, C.R. 1989. The patch dynamics concept of stream community ecology. Journal of the North American Benthological Society 8: $36-50$.

U.S. Geological Survey. 1993. Methods for collecting benthic macroinvertebtate samples as part of the national waterquality assessment program. USGS OpenFile Report 93-406, Denver, Colorado.

Vannote, R. L. and B. Sweeney. 1980. Geographic analysis of thermal equilibrium: a conceptual model for evaluating the effects of natural and modified thermal regimes on aquatic insect communities. American Naturalist 115(5): 667-695.

Vannote, R.L. 1973. Effects of natural temperatures on invertebrates. In: Effects and Methods of Evaluation of Thermal Discharges: 1228-1241. EPA report to Senate Subcommittee of Public Works, November, 1973.

Varley, T.D., and W.G. Brewster (eds.). 1992. Wolves for Yellowstone? V.10 Research and Analysis. National Park Service, Yellowstone National Park, Mammoth, Wyoming.

Ward, J.V. 1992. Aquatic Insect Ecology: 1. Biology and Habitat. John Wiley and Sons, Inc., New York. 
Ward, J.V. and B.C. Kondratieff. 1992. An Illustrated Guide to the Mountain Stream Insects of Colorado. University Press of Colorado, Niwot, Colorado.

Webb, K.M. and R.W. Merritt. 1987. The influence of diet on the growth of Stenonema vicarium. Hydrobiologia 153: 253-259.

Wesche, T.A., C.M. Goertler, and C.B. Frye. 1987. Contribution of riparian vegetation to trout cover in small streams. North American Journal of Fisheries Management 7: 151-153.
Wiederholm, T (ed.). 1986. Chironomidae of the Holartic Region. Part 1. Larvae. Entomologica Scandinavica Supplement 28, Sanby, Sweden.

Winegar, H.H. 1977. Camp Creek channel fencingplant, wildlife, soil, and water responses. Rangeman's Journal 4:10-12.

Zar, J.H. 1984. Biostatistical Analysis (2nd ed.). Prentice Hall, Englewood Cliffs, N.J. 